\title{
Comparison of the Degradation of the Polarisation Resistance of Symmetrical LSM- YSZ cells, with Anode Supported Ni-YSZ/YSZ/LSM-YSZ SOFCs
}

Torres da Silva, Iris Maura; Nielsen, Jimmi; Hjelm, Johan; Mogensen, Mogens Bjerg

Published in:

E C S Transactions

Link to article, DOI:

$10.1149 / 1.3205559$

Publication date:

2009

Document Version

Publisher's PDF, also known as Version of record

Link back to DTU Orbit

Citation (APA):

Torres da Silva, I. M., Nielsen, J., Hjelm, J., \& Mogensen, M. B. (2009). Comparison of the Degradation of the Polarisation Resistance of Symmetrical LSM-YSZ cells, with Anode Supported Ni-YSZ/YSZ/LSM-YSZ SOFCs. E C S Transactions, 25(2), 489-498. https://doi.org/10.1149/1.3205559

\section{General rights}

Copyright and moral rights for the publications made accessible in the public portal are retained by the authors and/or other copyright owners and it is a condition of accessing publications that users recognise and abide by the legal requirements associated with these rights.

- Users may download and print one copy of any publication from the public portal for the purpose of private study or research.

- You may not further distribute the material or use it for any profit-making activity or commercial gain

- You may freely distribute the URL identifying the publication in the public portal 


\title{
Comparison of the Degradation of the Polarization Resistance of Symmetrical LSM-YSZ Cells with Anode Supported Ni-YSZ/YSZ/LSM-YSZ SOFCs
}

\author{
I. M. Torres da Silva, J. Nielsen, J. Hjelm and M. Mogensen \\ Fuel Cells and Solid State Chemistry Division, Risø National Laboratory for Sustainable \\ Energy, Technical University of Denmark, DK-4000 Roskilde, Denmark \\ Impedance spectra of a symmetrical cell with SOFC cathodes \\ (LSM-YSZ/YSZ/LSM-YSZ) and an anode supported planar SOFC \\ (Ni-YSZ/YSZ/LSM-YSZ) were collected at OCV at $650^{\circ} \mathrm{C}$ in air \\ (cathode) and humidified (4\%) hydrogen (anode), over 155 hours. \\ The impedance was affected by degradation over time in the same \\ frequency range for both cells $(\sim 10 \mathrm{~Hz})$, possibly indicating that \\ the same physical process was affected in both types of cell. \\ However, deconvolution of the impedance data was not \\ straightforward. When $n$-values of the constant phase elements in \\ the otherwise identical equivalent circuit for the full cell were \\ changed slightly, very different results were obtained, showing the \\ high sensitivity of the fitting procedure. Therefore, the equivalent \\ circuit applied should be refined further, requiring comparison of \\ impedance data of the cells at higher temperature $\left(750,850^{\circ} \mathrm{C}\right)$.
}

\section{Introduction}

Symmetrical cells are a useful tool for screening electrode performance $(1,2)$. However, the performance of the cathode was found to be different on a full cell compared to on a symmetrical cell with a thick electrolyte (3). The experimentally determined full cell resistance was observed to be lower than expected from the sum of the losses from electrolyte and electrodes, obtained experimentally in separate single component tests (3).

The aim of this study was to investigate how the results collected from symmetrical cells relate to the results obtained on a corresponding full cell. Therefore, electrochemical impedance spectra (EIS) from a symmetrical cell with SOFC cathodes and a full cell were collected periodically over a longer period of time, at open circuit voltage (OCV) and $650^{\circ} \mathrm{C}$. The platform chosen was an anode supported planar SOFC; NiYSZ/YSZ/LSM-YSZ, an SOFC of continuing interest in the SOFC field $(4,5)$.

\section{Experimental}

\section{$\underline{\text { Cell Preparation }}$}

Symmetrical Cells. LSM-YSZ cathode layers were deposited by screen-printing on both sides of a tape-casted $5 \times 5 \mathrm{~cm}^{2}$ YSZ electrolyte strip ( 150-200 $\mu \mathrm{m}$ thick). The resulting symmetrical cells were cut to $5 \times 5 \mathrm{~mm}^{2}$ pieces and Pt paste (Ferro) was painted 
onto the cells. Prior to testing the Pt paste was sintered on the cell at $850^{\circ} \mathrm{C}$ for 2 hours in stagnant air.

Full Cells. Anode supported planar Ni-YSZ/YSZ/LSM-YSZ cells were produced, The anode support was prepared by tape casting and subsequently the active Ni-YSZ anode layer and YSZ electrolyte were spray painted onto the support. The half cells were then sintered and cut to $5 \times 5 \mathrm{~cm}^{2}$. Finally the LSM-YSZ cathode was screen-printed onto the half cells and the cell was sintered. The resulting cell had a $4 \times 4 \mathrm{~cm}^{2}$ active area and $\mathrm{Ni}$ and LSM contact layers were applied on the anode and cathode side, respectively. Further details on the cell production can be found elsewhere (6).

\section{$\underline{\text { Cell Characterization }}$}

Symmetrical cells. Four symmetrical cells were placed simultaneously in the same experimental setup. Each cell was placed between two Pt-grids. The holder was then placed in a furnace with stagnant air. Impedance spectra were recorded at 850, 800, 750, 700,650 and $600^{\circ} \mathrm{C}$ initially. Afterwards the temperature was kept constant at $650^{\circ} \mathrm{C}$ for 460 hours, while impedance spectra were obtained at regular intervals. The first 65 hours a Hioki 3522 impedance analyzer was used, from $0.2 \mathrm{~Hz}$ to $96.3 \mathrm{kHz}$, recording 12 points per decade. The next 400 hours, a Solartron 1260 impedance analyzer was connected, running from $0.14 \mathrm{~Hz}$ to $541 \mathrm{kHz}$, recording 12 points per decade. Impedance data were analyzed using Zview 2, commercially available software from Scribner Associates, Inc., with a complex nonlinear least square fitting routine built in.

Full Cell. The Ni-YSZ/YSZ/LSM-YSZ full cell was tested in an alumina test house, as described elsewhere $(1,7)$.

The cell test was carried out using $140 \mathrm{l} / \mathrm{h}$ air on the cathode side and $25 \mathrm{l} / \mathrm{h}$ of humidified (4\%) hydrogen on the anode side of the cell. The cell was kept at open circuit voltage $(\mathrm{OCV})$. Impedance spectra were recorded using a FuelCon TrueData-EIS impedance analyzer, running from $0.2 \mathrm{~Hz}$ to $82.5 \mathrm{kHz}$, recording 11 points per decade. Impedance spectra were obtained every 12 hours for 155 hours, at 850,750 and subsequently $650^{\circ} \mathrm{C}$.

\section{Results}

\section{$\underline{\text { Symmetrical Cells }}$}

Impedance data of the LSM-YSZ/YSZ/LSM-YSZ symmetrical cell were recorded in stagnant air. In Figure 1 the Nyquist representation of two spectra is shown; the first impedance spectrum recorded at $650^{\circ} \mathrm{C}$ and the other is the impedance spectrum from the same cell, which was recorded 156 hours later. Figure 2 shows the Bode plot with both the real and imaginary parts of the same impedance data. To give a clear view on at which frequency changes take place over time, in Figure 6 a difference plot of the imaginary part of the impedance is shown. 


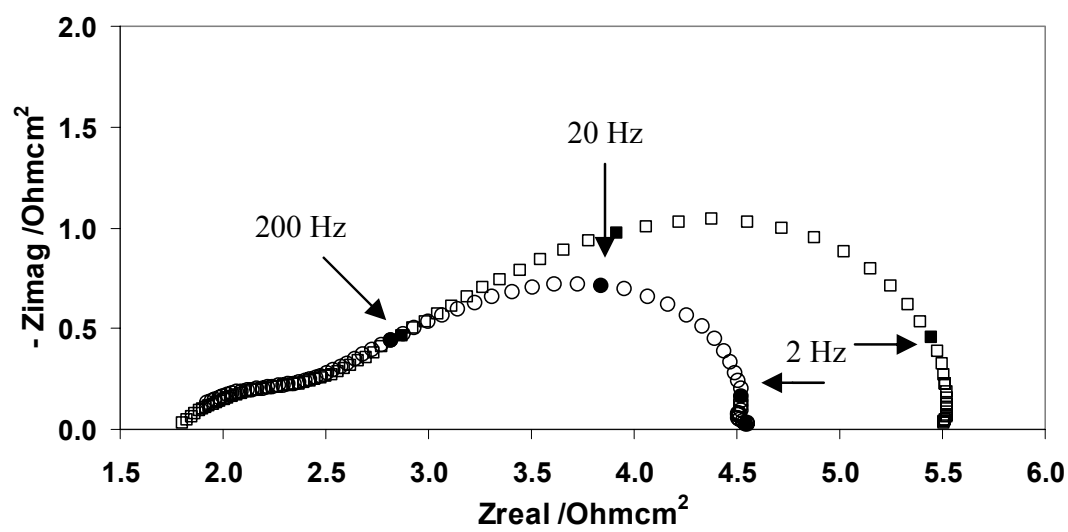

Figure 1. Nyquist plot of the electrochemical impedance obtained on LSMYSZ/YSZ/LSM-YSZ symmetrical cells, at $650^{\circ} \mathrm{C}$ in stagnant air. (o) Spectrum obtained after 0 hours of testing, ( $\square$ ) spectrum obtained after 156 hours of testing. Note that the spectrum shown is for the whole cell, hence contains data for 2 (equal) electrodes.

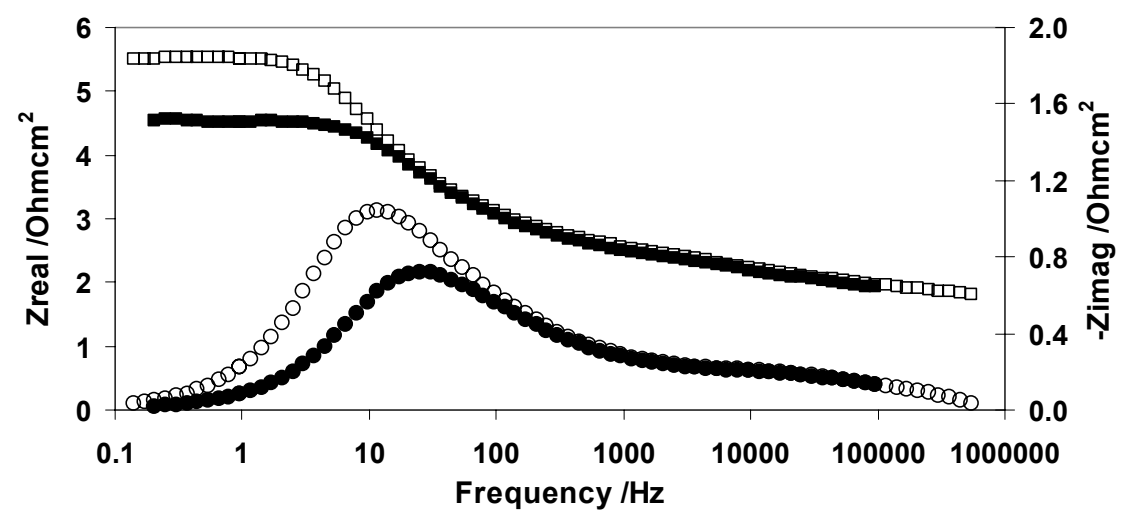

Figure 2. Bode plot of the real and imaginary parts of the electrochemical impedance obtained on the LSM-YSZ/YSZ/LSM-YSZ symmetrical cell, at $650^{\circ} \mathrm{C}$ in stagnant air. (匹) Real part of the impedance spectrum obtained after 0 hours of testing, ( $\square$ ) real part of the impedance spectrum obtained after 156 hours of testing. (•) Imaginary part of the impedance spectrum obtained after 0 hours of testing, ( $\circ$ ) imaginary part of the impedance spectrum obtained after 156 hours of testing. Note that the spectra shown for the symmetrical cell are for the whole cell, hence contains data for 2 (equal) electrodes.

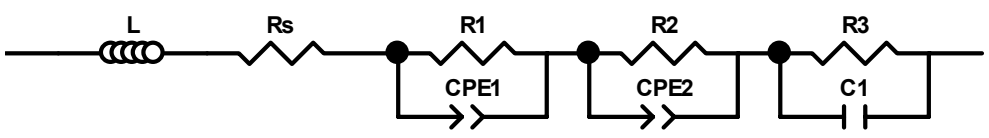

Figure 3. Equivalent circuit applied to deconvolute impedance data obtained on LSMYSZ/YSZ/LSM-YSZ symmetrical cells.

Impedance spectra of the LSM-YSZ/YSZ/LSM-YSZ symmetrical cells were deconvoluted using the equivalent circuit shown in Figure 3 (8). The inductance of the experimental setup was measured and fixed in the fitting procedure. First the $n$-values of the constant phase elements for the cathode contribution to the impedance, as proposed by Barfod et al. (2), were applied and fixed: $n=0.68$ for arc $1 ; n=0.87$ for arc 2 . While leaving the $R, Q$ and $C$ values to converge freely, it was not possible to obtain a satisfactory fit using these fixed $n$-values. Therefore, the $n$-values were allowed to 
converge freely as well. The best fit was obtained with $n=0.5$ for arc 1 and $n=0.8$ for $\operatorname{arc} 2$.

TABLE I. Fitting results of LSM-YSZ/YSZ/LSM-YSZ symmetrical cell at $650^{\circ} \mathrm{C}$, in stagnant air. Note that $R_{1}-R_{3}$ values, and therefore also the $R p$ value, are based on one electrode only.

\begin{tabular}{|c|c|c|c|c|}
\hline & $\mathbf{0 ~ h}$ & $156 \mathrm{~h}$ & Remarks & Physical process $(2,8)$ \\
\hline$L / H$ & $7.8 \mathrm{E}^{-8}$ & $7.8 \mathrm{E}^{-8}$ & fixed & \\
\hline $\mathrm{Rs} / \Omega \mathrm{cm}^{2}$ & 1.73 & 1.77 & & \\
\hline$R_{1} / \Omega \mathrm{cm}^{2}$ & 0.45 & 0.45 & fixed at $156 \mathrm{~h}$ & Transport/Transfer of \\
\hline & 0.5 & 0.5 & fixed at $156 \mathrm{~h}$ & oxide ions at the LSM/YSZ \\
\hline$C_{e q, 1} / F_{c m^{-2}}$ & $5.18 \mathrm{E}^{-6}$ & $5.18 \mathrm{E}^{-6}$ & fixed at $156 \mathrm{~h}$ & interface and through YSZ \\
\hline $\mathrm{f}_{\text {summit, } 1} / \mathrm{Hz}$ & 10227 & 10277 & & \\
\hline$R_{2} / \Omega \mathrm{cm}^{2}$ & 0.45 & 0.56 & & Dissociative adsorption of \\
\hline & 0.8 & 0.8 & fixed at $156 \mathrm{~h}$ & $\mathrm{O}_{2}$ followed by \\
\hline $\mathbf{f}_{\text {summit }, 2} / H z$ & 105 & 82 & & electrochemical reduction \\
\hline$C_{e q, 2} / F_{c m}-2$ & $5.04 \mathrm{E}^{-4}$ & $5.15 \mathrm{E}^{-4}$ & & $\begin{array}{c}\text { and transfer of oxygen } \\
\text { species at TPB }\end{array}$ \\
\hline$R_{3} / \Omega \mathrm{cm}^{2}$ & 0.51 & 0.87 & & Gas concentration \\
\hline $\mathrm{f}_{\text {summit }, 3} / \mathrm{Hz}$ & 18.5 & 9.6 & & \\
\hline $\mathrm{C}_{3} / \mathrm{Fcm}^{-2}$ & $2.50 \mathrm{E}^{-3}$ & $2.83 \mathrm{E}^{-3}$ & & \\
\hline$R p$ total $\left(R_{1}+R_{2}+R_{3}\right) / \Omega c^{2}$ & 1.41 & 1.88 & & \\
\hline
\end{tabular}

As can be seen from Figure 2 and 6, the main change of the impedance data over time takes place at approximately $10 \mathrm{~Hz}$. Therefore, the high frequency arc (arc 1) is not affected by this change. Fitting of the impedance data at 156 hours was carried out by allowing the $\mathrm{R}$ and $\mathrm{Q}$ values of arc 2 solely, arc 3 solely, or both arc 2 and 3 to converge freely. The first two fitting results were not satisfying, while the third was (chi-squared $<$ $5 \cdot 10^{-4}$ ). Therefore both arc 2 and 3 were considered to be affected by degradation over time. Table I shows the results of fitting of the impedance data at both 0 and 156 hours. The summit frequency $\left(f_{\text {summit }}\right)$ and equivalent capacitance $\left(C_{e q}\right)$ of all arcs were calculated as follows:

$$
\begin{aligned}
f_{\text {summit }} & =\left(\frac{1}{2 \pi}\right)(R Q)^{1 / n} \\
C_{e q} & =\frac{(R Q)^{1 / n}}{R}
\end{aligned}
$$

\section{$\underline{\text { Full cell }}$}

Impedance data were obtained on the Ni-YSZ/YSZ/LSM-YSZ cell at 850 and $650^{\circ} \mathrm{C}$. The Nyquist representation of impedance data sets at $650^{\circ} \mathrm{C}$, the first $(0 \mathrm{~h})$ and the last spectrum $(155 \mathrm{~h})$ obtained on the full cell, is shown in Figure 4. Furthermore in Figure 5 the Bode representations of the same impedance data sets are shown, for the real and imaginary part of the impedance. Finally, to determine at which frequency changes with time took place, a difference plot of the imaginary part of the two spectra is shown in Figure 6. 


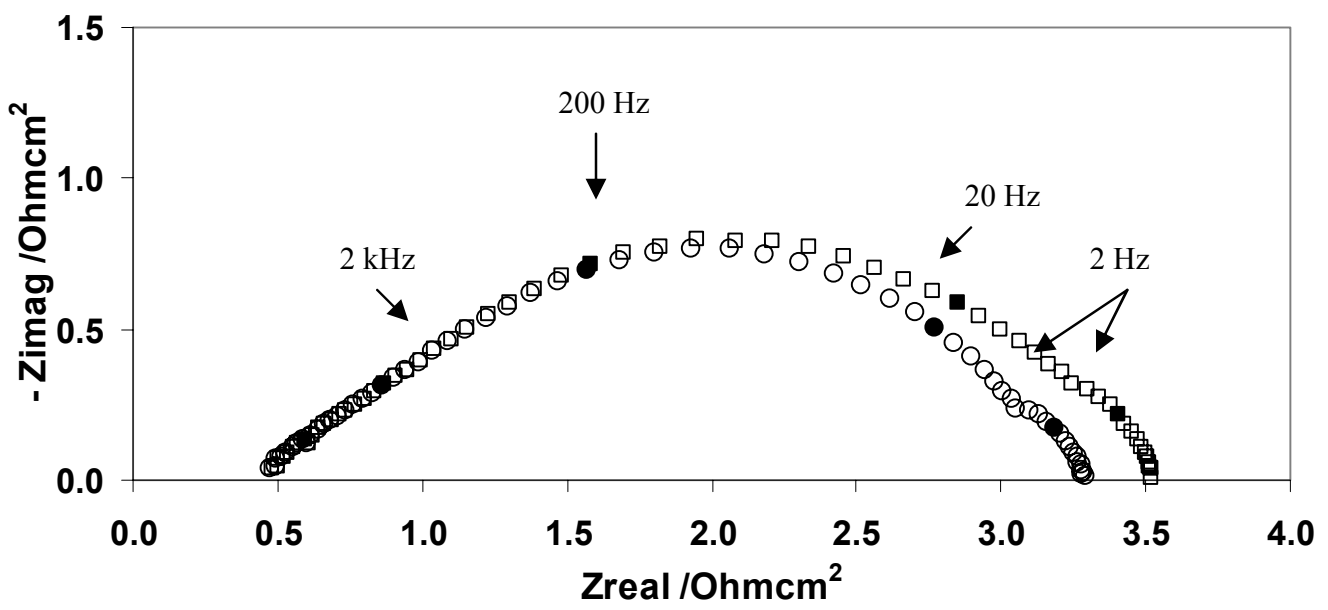

Figure 4. Nyquist plot of electrochemical impedance obtained on the Ni-YSZ/YSZ/LSMYSZ full cell. Conditions: $650^{\circ} \mathrm{C}, \mathrm{OCV}, 140 \mathrm{l} / \mathrm{h}$ air (cathode), $25 \mathrm{l} / \mathrm{h}$ humidified (4\%) hydrogen. ( $\odot$ ) Spectrum obtained after 0 hours of testing, ( $\square$ ) spectrum obtained after 155 hours of testing.

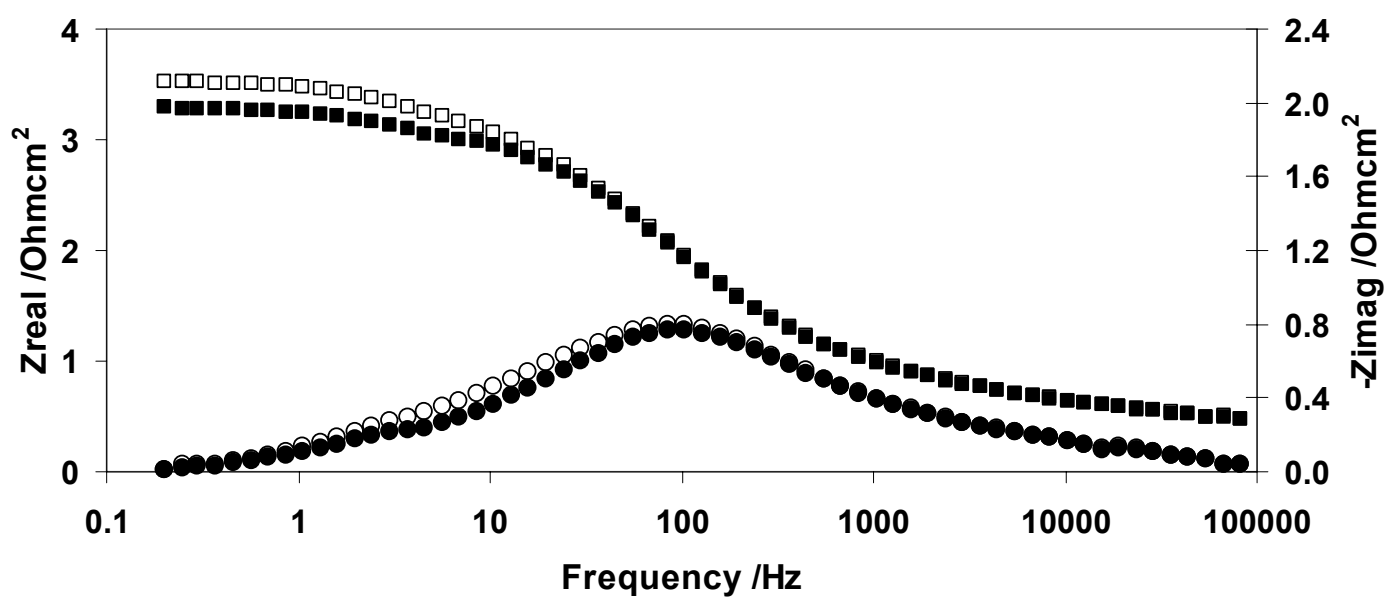

Figure 5. Bode plot of the real and imaginary part of the electrochemical impedance obtained on the Ni-YSZ/YSZ/LSM-YSZ full cell. Conditions: $650^{\circ} \mathrm{C}, \mathrm{OCV}, 140 \mathrm{l} / \mathrm{h}$ air (cathode), $25 \mathrm{l} / \mathrm{h}$ humidified (4\%) hydrogen. (ロ) Real part of the impedance spectrum obtained after 0 hours of testing, ( $\square$ ) real part of the impedance spectrum obtained after 155 hours of testing. ( $\bullet$ Imaginary part of the impedance spectrum obtained after 0 hours of testing, ( $($ ) imaginary part of the impedance spectrum obtained after 155 hours of testing.

Impedance spectra of full cells were deconvoluted using the equivalent circuit proposed by Barfod et al. $(2,10,11)$, see Figure 7 . The inductance was determined by fitting the impedance spectra at $850^{\circ} \mathrm{C}$, using fixed $n$-values for the constant phase elements (as proposed by Barfod et al. (2)), while allowing all other parameters to converge freely. Initial guesses based on the data found by Barfod et al. (2) were applied and the fit converged satisfactorily (chi-squared $<5 \cdot 10^{-4}$ ). Thereby, the inductance of the setup was determined to $9.4 \cdot 10^{-9} \mathrm{H}$ and this value was applied and fixed in the all further fitting of the full cell. 


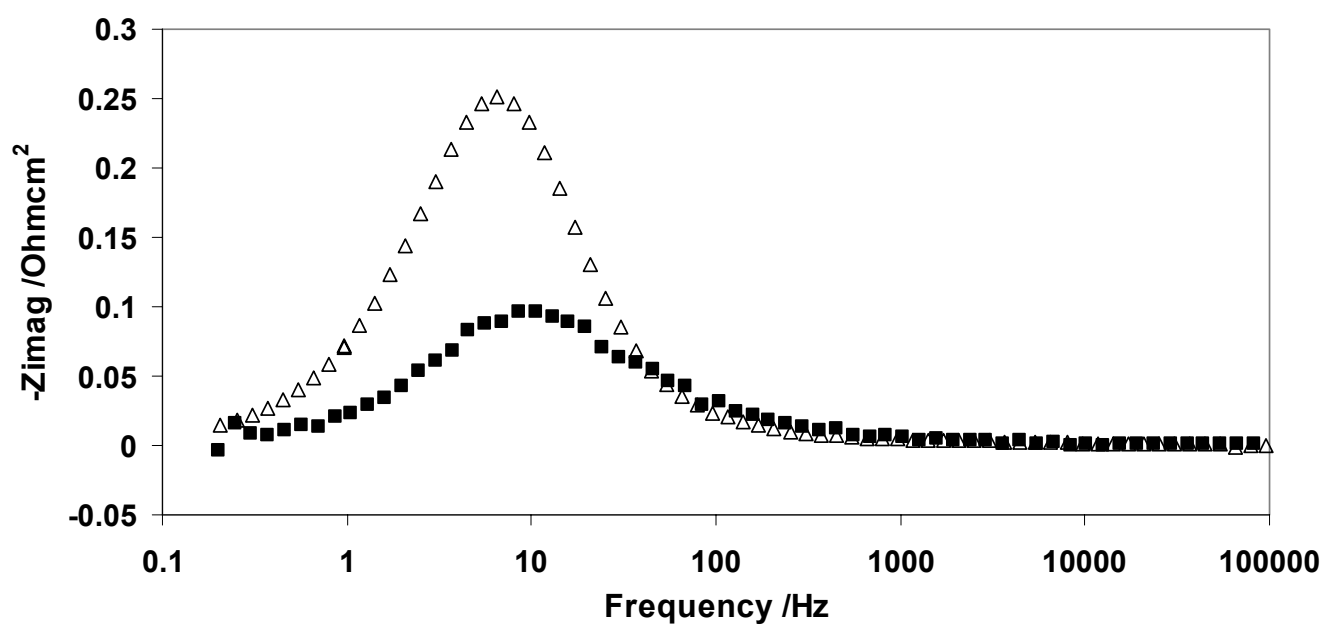

Figure 6. Difference plot of the imaginary part of the impedance data of the cells. The impedance data at $0 \mathrm{~h}$ were subtracted from those at 155/156 hours. ( $\square$ ) Full cell (NiYSZ/YSZ/LSM-YSZ); ( $\Delta$ ) symmetrical cell (LSM-YSZ/YSZ/LSM-YSZ), the imaginary part of the impedance data for the symmetrical cell were divided by two, so the values in the plot only represent one cathode.

Two sets of fixed $n$-values for the constant phase elements were applied using the same equivalent circuit. The first set consisted of the $n$-values as proposed by Barfod et al (11), who proposed these $n$-values based on comparison of symmetrical and full cell data at $850^{\circ} \mathrm{C}$, for cells with sprayed LSM-YSZ electrodes. However, the cathode symmetrical cell could not be fitted satisfactory with these $n$-values. This could be due to the facts that the LSM-YSZ cathodes of the cells used in this study were screen printed on the cells, unlike the cell used by Barfod, and that the data were obtained at a different temperature. Therefore, the $n$-values related to the cathode ( $\operatorname{arc} 1$ and 3 ) were adjusted to the $n$-values determined for the symmetrical cell in this study, giving a second set of $n$-values. Possibly, the $n$-values for the anode related processes should be adjusted as well, but since no anode symmetrical cell data at $650^{\circ} \mathrm{C}$ were available at the time of writing, these $n$-values were kept accordingly to Barfod et al. (2). The final sets of $n$-values are shown in Table II.

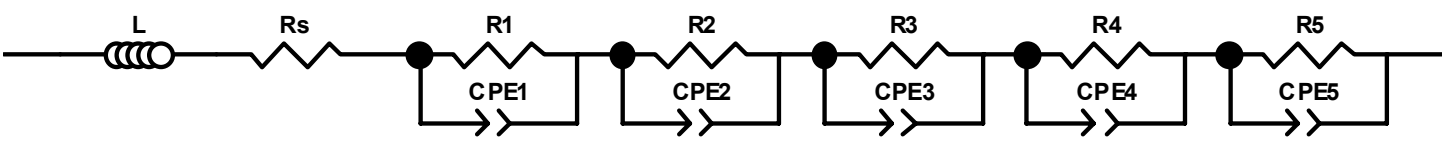

Figure 7. Equivalent circuit applied to deconvolute impedance data obtained on NiYSZ/YSZ/LSM-YSZ full cell.

The spectra obtained at $650^{\circ} \mathrm{C}$ were fitted to the equivalent circuit, fixing the inductance $\left(9.4 \cdot 10^{-9} \mathrm{H}\right)$ and fixing the two sets of $n$-values. At $0 \mathrm{~h}$ the impedance spectra were fitted satisfactory to the two sets of $n$-values. The values for chi-squared were very similar; the second set of $n$-values led to a $4 \%$ lower chi-squared value compared to the first set. However, the final result of the fit, in terms of distribution of the resistances over the different arcs, and thereby over the physical processes, was very different, as shown in Table II. 
As for the symmetrical cell, the main change between the spectra obtained at $155 \mathrm{~h}$ and $0 \mathrm{~h}$ was observed at around $10 \mathrm{~Hz}$. For the full cell this means the change affected either arc 3, 4, 5 or a combination of two or three of them. For each set of $n$-values, the spectrum at $155 \mathrm{~h}$ was fitted seven times, allowing the R and Q values of only arc 3, 4 or 5 , a combination of two, or all three arcs, to converge freely. In case of the first set of $n$ values, the most satisfactory fit was obtained by allowing solely $R$ and $Q$ of arc 4 to converge freely. When allowing the $\mathrm{R}$ and $\mathrm{Q}$ values of arc 3, 4 and 5 to converge freely simultaneously, the values for arc 3 and 5 changed minimally. Therefore the fit allowing $\mathrm{R}$ and $\mathrm{Q}$ of arc 4 to converge freely was applied as the final one. In case of the second set of $n$-values the best fit was obtained when allowing the $\mathrm{R}$ and $\mathrm{Q}$ values of all three arcs to converge freely.

Even though satisfactory (chi-squared $<5 \cdot 10^{-4}$ ) results were obtained for both sets of $n$-values, the chi-squared value for the second set of $n$-values was two times lower, indicating a better fit using this set of $n$-values. As for the fit at $0 \mathrm{~h}$, the distribution of resistances was also significantly different for either set of $n$-values at $155 \mathrm{~h}$. The values for the final fits, using both sets of $n$-values, at 0 and $155 \mathrm{~h}$, are given in Table II.

TABLE II. Fitting results of Ni-YSZ/YSZ/LSM-YSZ full cell at $650^{\circ} \mathrm{C}, \mathrm{OCV}, 140 \mathrm{l} / \mathrm{h}$ air (cathode) and 25 1/h humidified (4\%) hydrogen.

\begin{tabular}{|c|c|c|c|c|c|c|c|}
\hline & \multicolumn{3}{|c|}{$n$-values from Barfod et al. (2) } & \multicolumn{3}{|c|}{$\begin{array}{l}n \text {-values from Barfod et al. ( } 2 \text { ) } \\
\text { combined with symmetrical cell } \\
\text { equivalent circuit (this study) }\end{array}$} & \multirow[b]{2}{*}{ Physical process (2) } \\
\hline & $\mathbf{0 ~ h}$ & $155 \mathrm{~h}$ & Remarks & O h & $155 \mathrm{~h}$ & Remarks & \\
\hline$L / H$ & $9.4 \mathrm{E}^{-9}$ & $9.4 \mathrm{E}^{-9}$ & fixed & $9.4 \mathrm{E}^{-9}$ & $9.4 \mathrm{E}^{-9}$ & fixed & \\
\hline $\mathrm{Rs} / \mathrm{Qcm}^{2}$ & 0.37 & 0.37 & & 0.27 & 0.28 & & \\
\hline$R_{1} / \Omega \mathrm{cm}^{2}$ & 0.32 & 0.32 & $\begin{array}{l}\text { fixed at } \\
155 \mathrm{~h}\end{array}$ & 0.41 & 0.41 & $\begin{array}{l}\text { fixed at } \\
155 \mathrm{~h}\end{array}$ & $\begin{array}{l}\text { Transport/Transfer of } \\
\text { oxide ions at the }\end{array}$ \\
\hline & 0.68 & 0.68 & fixed & 0.5 & 0.5 & fixed & LSM/YSZ interface and \\
\hline $\mathrm{f}_{\text {summit, } 1} / H z$ & 30423 & 30423 & & 68072 & 68072 & & through YSZ \\
\hline$C_{e q, 1} / F_{c m}^{-2}$ & $2.62 \mathrm{E}^{-4}$ & $2.62 \mathrm{E}^{-4}$ & $\begin{array}{l}\text { fixed at } \\
155 \mathrm{~h}\end{array}$ & $9.14 \mathrm{E}^{-5}$ & $9.14 \mathrm{E}^{-5}$ & $\begin{array}{c}\text { fixed at } \\
155 \mathrm{~h}\end{array}$ & \\
\hline$R_{2} / \Omega \mathrm{cm}^{2}$ & 0.59 & 0.59 & $\begin{array}{c}\text { fixed at } \\
155 \mathrm{~h}\end{array}$ & 0.21 & 0.21 & $\begin{array}{c}\text { fixed at } \\
155 \mathrm{~h}\end{array}$ & $\begin{array}{l}\text { Dissociative adsorption } \\
\text { of } \mathrm{H}_{2} \text {, transport at the }\end{array}$ \\
\hline$n_{2}$ & 0.80 & 0.80 & fixed & 0.8 & 0.8 & fixed & triple phase boundary \\
\hline $\mathbf{f}_{\text {summit, } 2} / \mathrm{Hz}$ & 855 & 855 & & 2540 & 2540 & & (TPB) \\
\hline$C_{e q, 2} / \mathrm{Fcm}^{-2}$ & $5.08 \mathrm{E}^{-3}$ & $5.08 \mathrm{E}^{-3}$ & $\begin{array}{c}\text { fixed at } \\
155 \mathrm{~h}\end{array}$ & $4.75 \mathrm{E}^{-3}$ & $4.75 \mathrm{E}^{-3}$ & $\begin{array}{c}\text { fixed at } \\
155 \mathrm{~h}\end{array}$ & \\
\hline$R_{3} / \Omega m^{2}$ & 1.57 & 1.57 & $\begin{array}{c}\text { fixed at } \\
155 \mathrm{~h}\end{array}$ & 1.57 & 0.99 & & $\begin{array}{c}\text { Dissociative adsorption } \\
\text { of } \mathrm{O}_{2} \text { followed by }\end{array}$ \\
\hline & 0.87 & 0.87 & fixed & 0.8 & 0.8 & fixed & electrochemical \\
\hline $\mathbf{f}_{\text {summit, } 3} / \mathrm{Hz}$ & 84 & 84 & & 82 & 45 & & reduction and transfer of \\
\hline$C_{e q, 3} / \mathrm{Fcm}^{-2}$ & $1.94 \mathrm{E}^{-2}$ & $1.94 \mathrm{E}^{-2}$ & $\begin{array}{c}\text { fixed at } \\
155 \mathrm{~h} \\
\end{array}$ & $1.97 \mathrm{E}^{-2}$ & $5.75 \mathrm{E}^{-2}$ & & oxygen species at TPB \\
\hline$R_{4} / \Omega \mathrm{cm}^{2}$ & 0.06 & 0.49 & & 0.49 & 1.39 & & Gas-phase diffusion \\
\hline$n_{4}$ & 0.75 & 0.75 & fixed & 0.75 & 0.75 & fixed & (mainly anode side) \\
\hline $\mathbf{f}_{\text {summit, } 4} / H z$ & 20 & 13 & & 278 & 140 & & \\
\hline$C_{e q, 4} / \mathrm{Fcm}^{-2}$ & 2.11 & 0.40 & & $1.87 \mathrm{E}^{-2}$ & $1.31 \mathrm{E}^{-2}$ & & \\
\hline$R_{5} / \Omega \mathrm{cm}^{2}$ & 0.20 & 0.20 & $\begin{array}{l}\text { fixed at } \\
155 \mathrm{~h}\end{array}$ & 0.17 & 0.24 & & $\begin{array}{c}\text { Gas conversion } \\
\text { (mainly anode side) }\end{array}$ \\
\hline$n_{5}$ & 1.00 & 1.00 & fixed & 1.00 & 1.00 & fixed & \\
\hline $\mathbf{f}_{\text {summit }, 5} / H z$ & 2.4 & 2.4 & & 2.4 & 3.5 & & \\
\hline$C_{e q, 5} / \mathrm{Fcm}^{-2}$ & 5.34 & 5.34 & $\begin{array}{c}\text { fixed at } \\
155 \mathrm{~h} \\
\end{array}$ & 6.54 & 3.07 & & \\
\hline $\begin{array}{l}\text { Rp cathode total } \\
\left(R_{1}+R_{3}\right) / \Omega \mathrm{cm}^{2}\end{array}$ & 1.89 & 1.89 & & 1.98 & 1.40 & & \\
\hline
\end{tabular}




\section{$\underline{\text { Comparison of Symmetrical and Full Cell Data }}$}

To be able to compare the degradation of symmetrical and SOFCs, the degradation rates (in $\mathrm{m} \Omega \mathrm{cm}^{2} / \mathrm{h}$ and in $\% / \mathrm{h}$ ) were determined; a summary is given in Table III.

TABLE III. Degradation of the SOFC cathode polarization resistance on the symmetrical and full cell, and of the polarization resistance of the full cell. Note that $R p$ given for the symmetrical cell is based on one electrode and $R p$ given for the full cell is based on $R_{I}$ and $R_{3}$.

\begin{tabular}{|c|c|c|c|c|}
\hline Cell type & $\begin{array}{l}R p(0 \mathrm{~h}) \\
/ \Omega \mathrm{cm}^{2}\end{array}$ & $\begin{array}{c}R p(155 / 156 \mathrm{~h}) \\
/ \Omega \mathrm{cm}^{2}\end{array}$ & $\begin{array}{c}\text { Degradation rate } \\
R p / \mathrm{m} \Omega \mathrm{cm}^{2} / \mathrm{h}\end{array}$ & $\begin{array}{c}\text { Degradation rate } \\
R p / \% / h\end{array}$ \\
\hline $\begin{array}{l}\text { Cathode symmetrical cell } \\
\text { (one electrode) }\end{array}$ & 1.47 & 2.65 & 3.04 & 0.22 \\
\hline $\begin{array}{l}\text { Full cell; cathode contributions } \\
\left(1^{\text {st }} \text { set } n \text {-values }\right)\end{array}$ & 1.89 & 1.89 & 0 & 0 \\
\hline $\begin{array}{l}\text { Full cell; cathode contributions } \\
\left.\text { ( } 2^{\text {nd }} \text { set } n \text {-values }\right)\end{array}$ & 1.98 & 1.40 & -3.74 & -0.19 \\
\hline $\begin{array}{l}\text { Full cell; all contributions } \\
\left(1^{\text {st }} \text { set } n \text {-values }\right)\end{array}$ & 2.74 & 3.17 & 2.75 & 0.10 \\
\hline $\begin{array}{l}\text { Full cell; all contributions } \\
\left(2^{\text {nd }} \text { set } n \text {-values }\right)\end{array}$ & 2.85 & 3.24 & 2.54 & 0.09 \\
\hline
\end{tabular}

\section{Discussion}

The testing history of the LSM-YSZ/YSZ/LSM-YSZ symmetrical cell and the NiYSZ/YSZ/LSM-YSZ full cell were not entirely the same. Before recording impedance spectra at $650^{\circ} \mathrm{C}$, the symmetrical cell has only undergone a short, 27 hour, temperature cycle from 850 to $600^{\circ} \mathrm{C}$, while recording impedance spectra at each step of $50^{\circ} \mathrm{C}$. The full cell however, was heated to $1000^{\circ} \mathrm{C}$ at start up of the experiment. Thereafter impedance spectra were recorded every 12 hours for 155 hours at $850^{\circ} \mathrm{C}$ and $750^{\circ} \mathrm{C}$, before recording impedance spectra at $650^{\circ} \mathrm{C}$.

Furthermore, the symmetrical cell was tested in stagnant air, while the cathode of the full cell was exposed to $140 \mathrm{l} / \mathrm{h}$ of compressed air. This may influence the amount and possibly type of contaminants present in the cells, at the critical interfaces, and thus might influence the degradation of the cathode.

Interestingly, as can be seen in Figures 2, 5 and 6, degradation of both cell types affected the impedance response of the cells in approximately the same frequency range $(\sim 10 \mathrm{~Hz})$. This may indicate that the same physical processes were affected by degradation over time.

However, initial fitting of the impedance data to equivalent circuits did not lead to a satisfactory breakdown of losses, caused by the fact that there were too many unknown factors and the fitting procedure was very sensitive to small changes in the fixed $n$-values. Breakdown of losses for the symmetrical cell showed that both the low frequency cathode arc (dissociative adsorption of oxygen at the triple phase boundary) and the gas concentration impedance appeared to be affected by degradation with time. The breakdown of losses of the full cell, however, depended strongly on the applied set of $n$ values, in an otherwise identical equivalent circuit. By applying a first set of $n$-values, as proposed by Barfod et al. (2), the gas concentration impedance appeared to be affected only, indicating no degradation of the cathode impedance. However, when applying a second set of $n$-values, with adjusted $n$-values for the cathode contribution as determined 
from the symmetrical cell, the breakdown of losses was significantly different. In this case both the gas concentration impedance and the impedance from the low frequency cathode arc appeared to be affected by degradation of the cell with time. However, the dissociative adsorption of oxygen impedance did not appear to increase with time in the latter case, as appeared to be the case for the symmetrical cell, but instead appeared to decrease. Nonetheless, the total polarization resistance increased; the decrease in the low frequency cathode arc was balanced by a higher increase in the gas concentration impedance.

Clearly, deconvolution of the electrochemical impedance data obtained at $650^{\circ} \mathrm{C}$ was not straightforward. By slightly changing the $n$-values for the constant phase elements applied in the equivalent circuit, very different breakdown of losses were obtained, showing the sensitivity of the fitting procedure. When applying the second set of $n$-values the $R s$ value was lower than expected. Moreover, we are not aware of any mechanism that could explain a change of the concentration impedance with time, which leads us to conclude that neither of the applied equivalent circuits was able to give a correct breakdown of losses. Therefore, a further refinement of the equivalent circuits, for both the symmetrical and the full cell will be made. This might include replacing one or more of the RQ-elements by more complex Warburg or Gerischer elements. To support the refinement of the equivalent circuits further data will be obtained, including impedance data at higher temperatures $\left(750^{\circ} \mathrm{C}\right.$ and $\left.850^{\circ} \mathrm{C}\right)$.

Furthermore, as the data presented in this manuscript are based on only one cell of each type, further experiments are required to check the reproducibility of the data. A follow-up full cell test will be carried out for a longer period of time; at least 500 hours. Furthermore, experiments on the symmetrical cell type will be carried out in flowing air. Afterwards, experiments using different gas conditions, for example applying a higher humidification of the hydrogen fuel gas on the anode side, or applying oxygen on the cathode side, might give more insight into the comparability of the different types of cells. Finally, as SOFCs are normally used under current, a full cell should be investigated under current, to see to what extend comparison of symmetrical cells at OCV with full cells under current is useful.

\section{Conclusion}

At first glance, the LSM-YSZ/YSZ/LSM-YSZ symmetrical cell and the NiYSZ/YSZ/LSM-YSZ full cell show very similar degradation results at open circuit voltage at $650^{\circ} \mathrm{C}$ in air. The frequency range affected by degradation was observed to be around $10 \mathrm{~Hz}$ for both cells. However, deconvolution of the impedance spectra to determine the breakdown of losses was not straightforward. Applying slightly different $n$ values for the constant phase elements; $n$-values proposed in literature or $n$-values determined in this study, in an otherwise identical equivalent circuit, led to very different results for the breakdown of losses of the full cell, showing the high sensitivity of the fitting procedure. Moreover, both sets of $n$-values delivered unexpected and non physical breakdown of losses. Further data are required to refine the equivalent circuit applied for both the symmetrical and full cells, possibly including Warburg or Gerischer elements in the place of RQ elements. Hence, further investigation at different temperatures is planned. 


\section{Acknowledgments}

This work was supported financially by The Programme Commission on Sustainable Energy and Environment, The Danish Council for Strategic Research, via the Strategic Electrochemistry Research Center (www.serc.dk), contract no. 2104-06-0011.

\section{References}

1. M. Mogensen and P. V. Hendriksen, in High Temperature Solid Oxide Fuel Cells - Fundamentals, Design and Applications, S. C. Singhal and K. Kendall, Editors, p.261, Elsevier, Oxford (2003).

2. R. Barfod, M. Mogensen, T. Klemensø, A. Hagen, Y. -L. Liu and P. V. Hendriksen, J. Electrochem. Soc., 154, B371 (2007).

3. S. Primdahl, P. V. Hendriksen, P. H. Larsen, B. Kindl and M. Mogensen, H. Yokokawa and S. C. Singhal, Editors, p. 932, The Electrochemical Society, INC, Pennington, NJ, USA (2001).

4. S. B. Adler, Chemical Review, 104, 4791 (2004).

5. S. P. Jiang, Journal of Material Science, 43, 6799 (2008).

6. P. H. Larsen, C. Bagger, S. Linderoth, M. Mogensen, S. Primdahl, M. J. Jørgensen, P. V. Hendriksen, B. Kindl, N. Bonanos, F. W. Poulsen and K. A. Maegaard, in Proceedings. 7 International Symposium on Solid Oxide Fuel Cells (SOFC-VII), S. C. Singhal and H. Yokokawa, Editors, p. 28, Electrochemical Society, Pennington, NJ, USA (2001).

7. A. Hagen, M. Menon, R. Barfod, P. V. Hendriksen, S. Ramousse and P. H. Larsen, Fuel Cells, 6, 146 (2006).

8. M. J. Jørgensen and M. Mogensen, J. Electrochem. Soc., 148, A433 (2001).

9. T. Jacobsen, B. Zachau-Christiansen, L. Bay and S. Skaarup, in High Temperature Electrochemistry: Ceramics and Metals, Proceedings of the 17th Riso International Symposium on Materials Science, F. W. Poulsen, N. Bonanos, S. Linderoth, M. Mogensen and B. Zachau-Christiansen, Editors, p. 29, Riso Natl. Lab, (1996).

10. R. Barfod, A. Hagen, S. Ramousse, P. V. Hendriksen and M. Mogensen, Fuel Cells, 6, 141 (2006).

11. T. Ramos, J. Hjelm, M. Wandel, A. Hagen and M. Mogensen, ECS Transactions, 13, 235 (2008). 